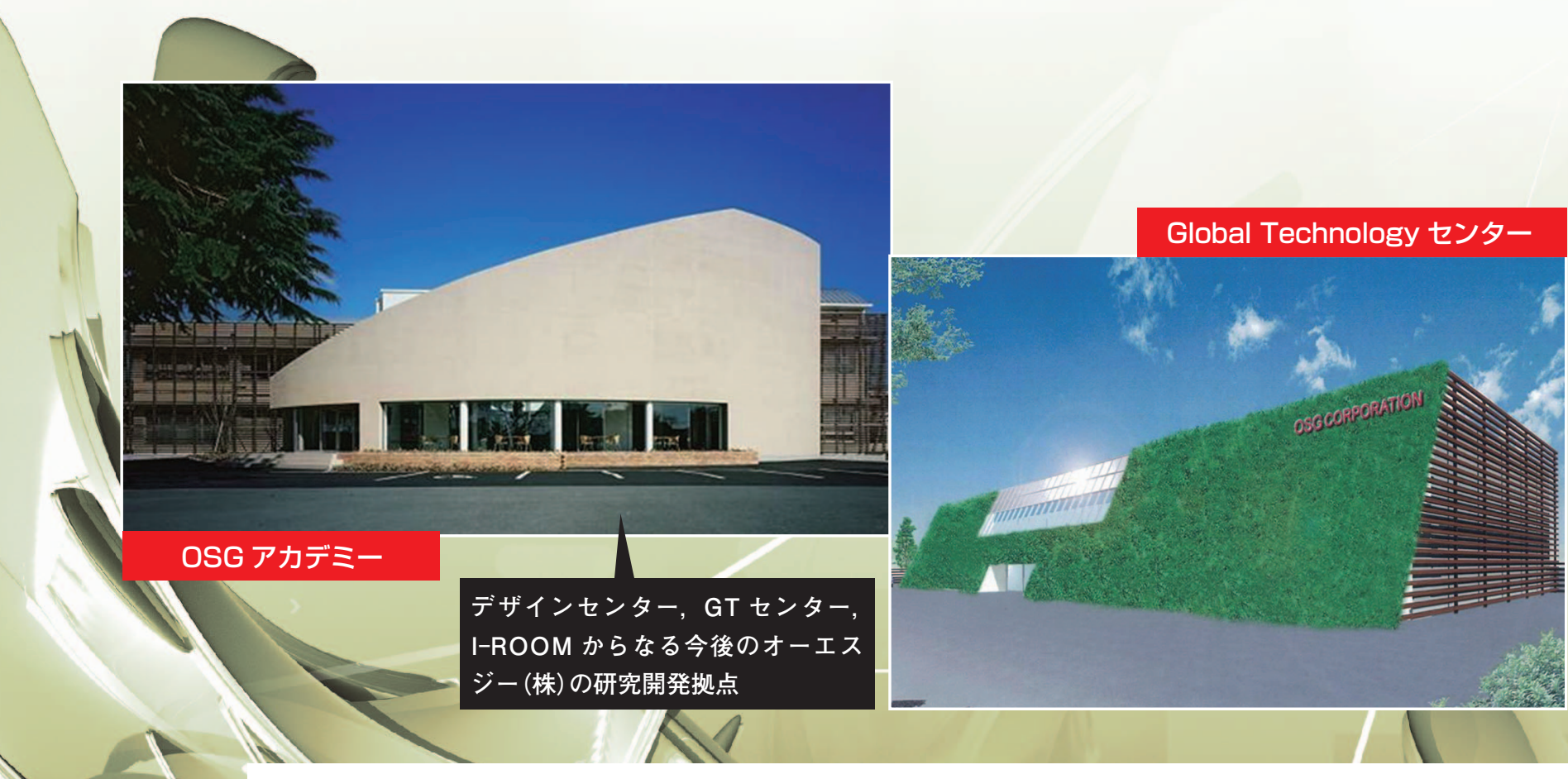

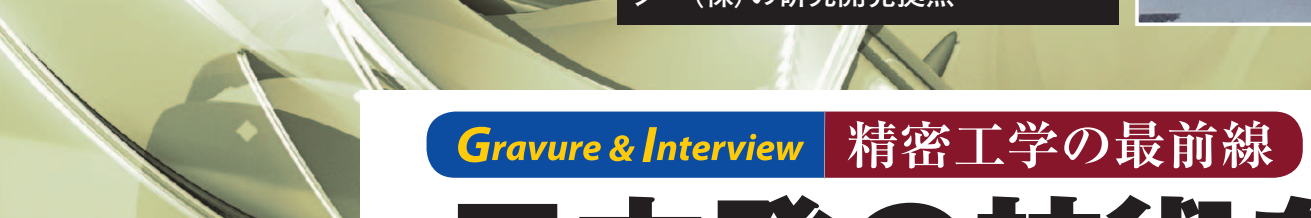

$$
\begin{aligned}
& \text { 日本発の技術を育て } \\
& \text { 世界一を目指す }
\end{aligned}
$$

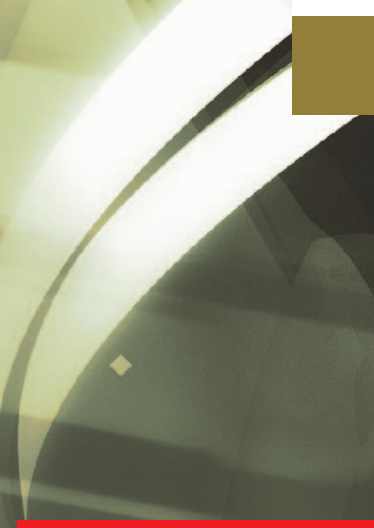
八名工場・ねじ研削ライン

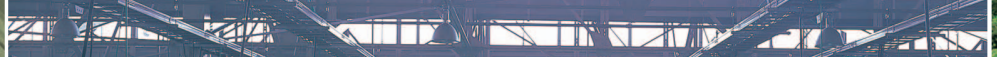

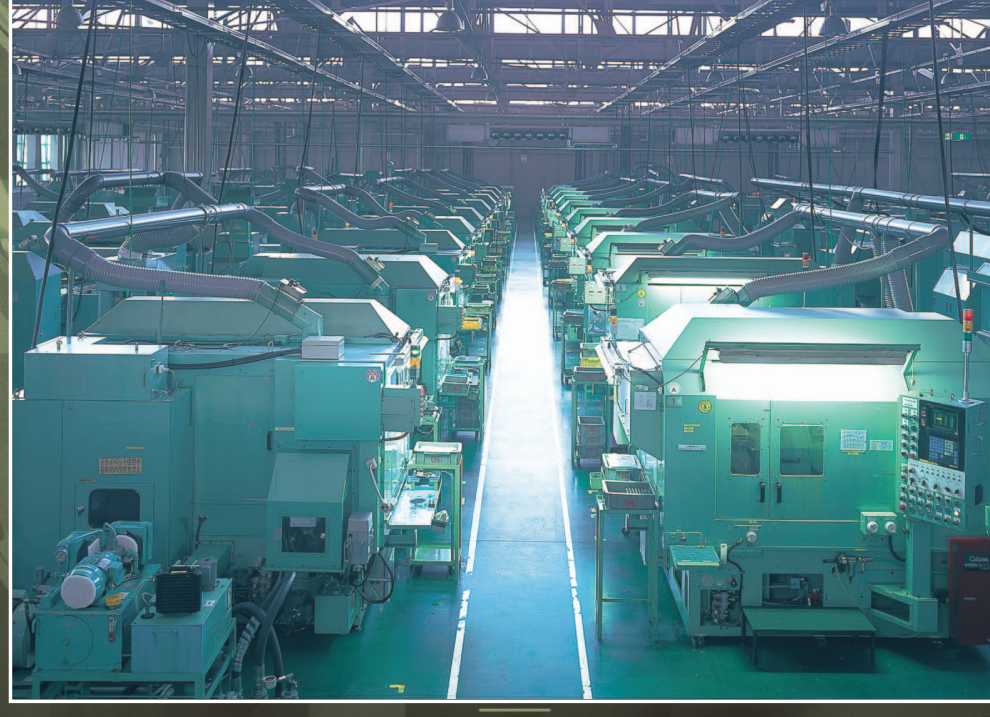

オーエスジー株式会社 デザインセンター
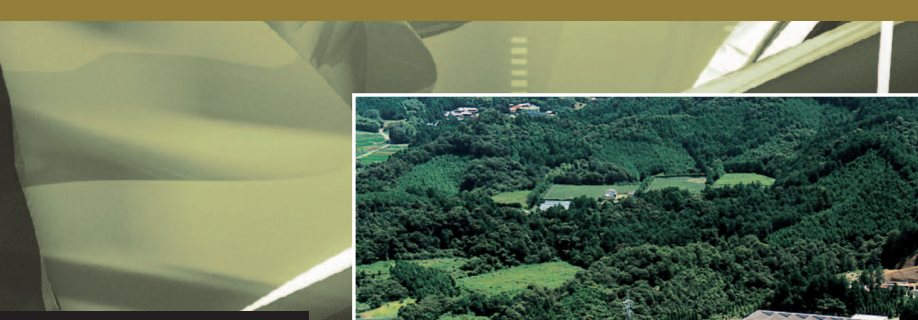

独自に開発したねじ研削盤 が並ぶ一固有技術が光る一 
Gravure \& Interview 精密工学の最前線

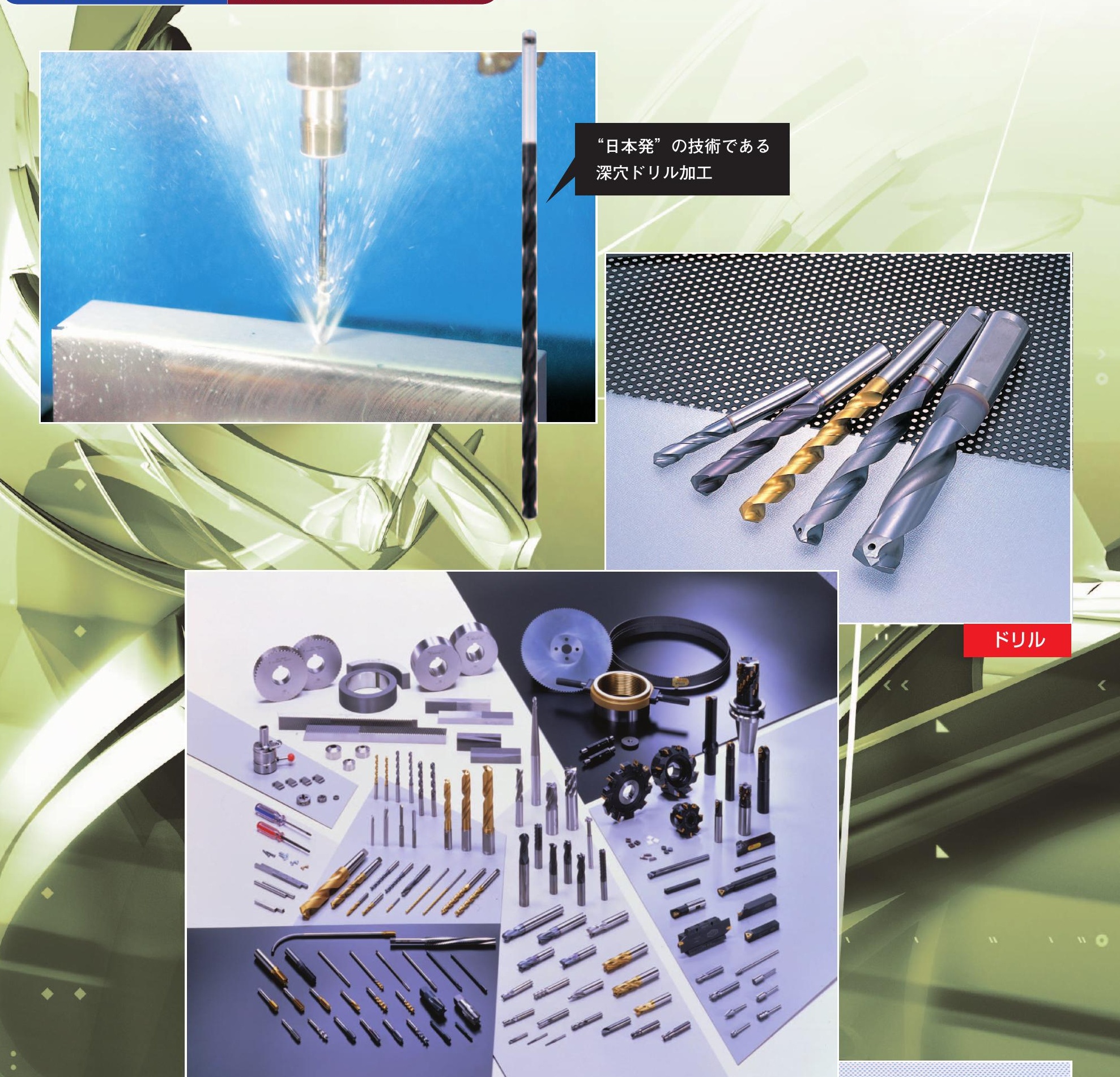

OSG 製品群
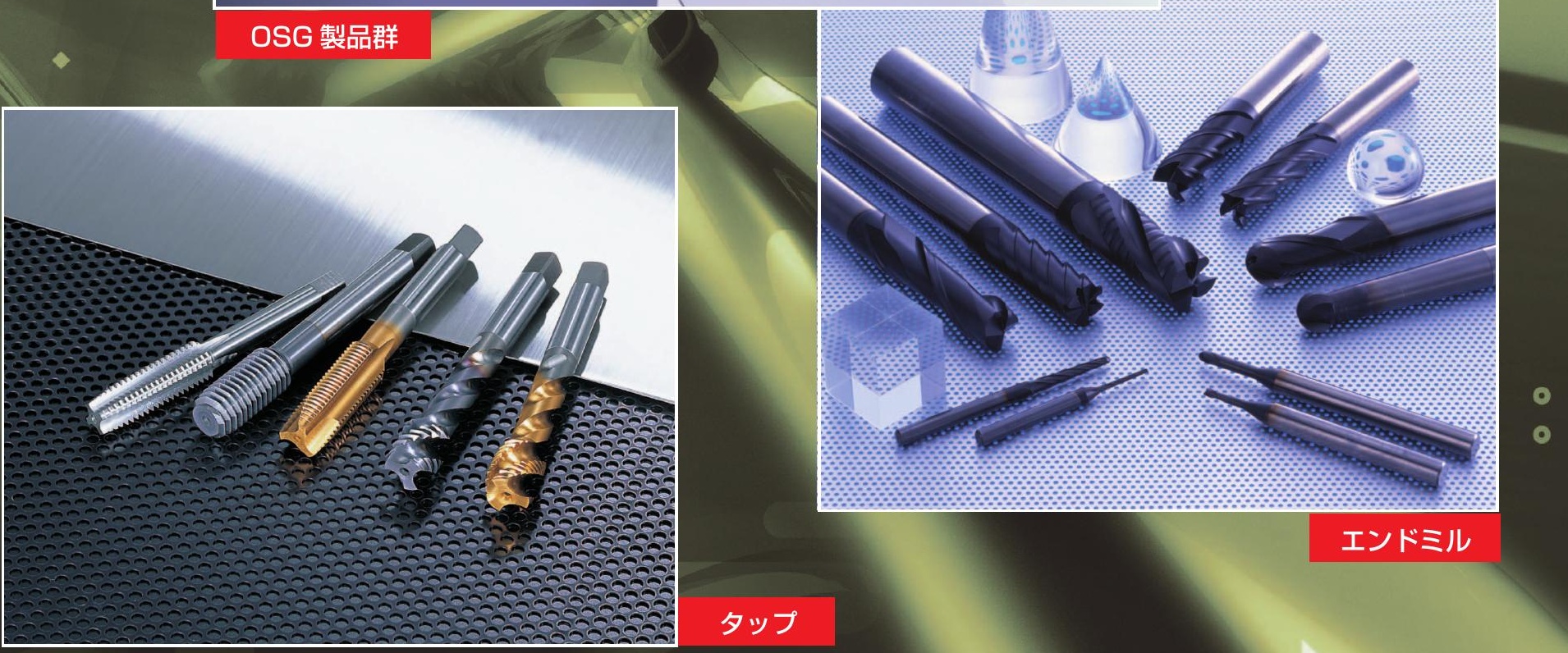


\section{日本発の技術を育て 世界一を目指す}

Q 最初に貴社の沿革と概要につ いてお聞かせ下さい.

A 当社は 1938 年, 創業者である大 沢秀雄が東京・武蔵野町に株式会社大 沢螺子研削所を設立したことにはじま ります、その名の通り, 創業は夕ップの 製造から出発しました. 現在ではタッ プの他, エンドミル, ドリルなどの切削 工具や転造工具なども開発・製造して おります：実は当地は戦時中の疎開工 場だったのですが,東京の工場が戦争 で壞滅したものですから, 創業者の生 誕地であるここ(愛知県豊川市一宮町) に本社を移しました，そのため，当地は 第 2 の創業の地といえましょう. 現在, 本社は別(同市本野々原)に移りました が,今後はここを当社の研究機関の中 心にしょうと考えています。

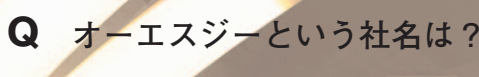

A 1963 年に改称しました。当社 の商号であり，登録商標でもありま す、創業者である大澤秀雄の「O」, SCREW/ねじの「S」, GRINDING/研 削の「G」の頭文字を組みあわせたも のです

$Q$ 貴社の製品ラインアップには $\mathrm{G}$ に関連するものは少ないと思うの ですが. これはタップやドリルの製造 において, 研削加工がキーテクノロジ ーということでしょうか.

A まさしくそうですね. 当社が 「株式会社大沢螺子研削所」として創 業したことからもおわかりになると思 いますが，タップ技術の源は「ねじを 研削する技術」なのですね．このねじ を研削する技術というのは, タップに 「ねじリリーブ」という機構をつけな ければならない特殊な研削盤が必要に なります，その特殊な研削盤を自社で 開発して, 少しずつタップの事業を拡

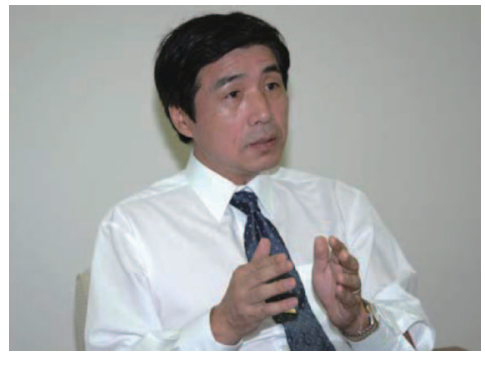

オーエスジ一株式会社 デザインセンター

取締役 デザインセンター長

〔次期代表取締役社長 (2007 年 2 月 17 日付就任予定)〕 石川 則男氏

インタビュア/金沢大学 細川 晃
大してきたわけです。そして，そこか ら派生した技術でもって，金型を加工 するエンドミル，自動車部品等に使わ れるドリル、ボルトやねじを塑性変形 によって加工する転造工具と展開して きました。この転造工具というのは自 動車のスプラインやウォームなど軸物 の部品の大量生産に使用する技術とし て将来性があると考えております。

Q さて，今回の企画は「これが世 界一! 日本の技術力」なのですが, 貴 社の「世界一」についてお話下さい.

A そうですね．「世界一の技術力」 と評価いただくのは大変うれしいので すが, 私はそのようにはうぬぼれては いないのですけどね. しかし，この企 画に沿うような話題を提供するという ことで，敢えていわせていただけるな らば，やはりタップ,それと転造工具 でしょうか.また，当社に限定せず， 我が国の技術力と言うことであれば, 深穴用超硬ドリルが挙げられると思い ます。間違いなくこれは“日本発”の 技術であり，日本の工作機械メーカと 工具メーカといろいろなニーズが合体 してできた工具と言えると思います。

Q そうですか. それでは，それ ぞれの工具について，もう少し詳しく 教えて下さい. まず, タップですが, 貴社には“世界一のタップ工場” とも 言える八名工場がありますが, シェア 世界一を維持している理由といいます か, 貴社固有の技術・製品の特徵など についてお聞かせ下さい.
A はい. タップに限ったことでない かもしれませんが, タップは素材と熱 処理が非常に重要になります。OSG では創業以来, ハイス工具に対しては 「硬ければ硬いほうがいい」という信 念があります。しかし，それを達成す るためには硬くても䩲性がある熱処理 技術が必要になります。ここに固有技 術があるのです。ただし，硬くすると 研削時に焼けやすくなります。特に， ねじというのは機構上研削焼けが発生 しやすい形状をしています。これを研 削盤自体の開発を含めた独自の研削技 術，固有技術によって解決しました。 創業以来, タップをつくる技術・設備 に関しては，ほぼ自社で完結できると いうところが強みではないでしょう か.

もう少しお話しいたしますと,一般 的なタップはバナジウム系ハイスが主 流で,バナジウム炭化物の大きさが硬 さや耐摩耗性を左右するのですが, こ れをコントロールするのが非常に難し い. 本来母材から開発すべきなのでし ようが, 大変コストがかかります.そこ で, 今は一般的なバナジウムハイスを 購入し, 熱処理と研削技術でねらった 性能を出す,いわば「料理人次第」に変 わっています.当社には世界一の料理 人がいるといえるかもしれませんね。

Q なるほどよくわかりました、転 造タップとはどのようなものですか.

A 背景から説明いたしますと，何 年か前から自動車のタップに対する考 え方が変わってきまして，昨今はマシ ニングセンタのラインですから, 単軸 


\section{Gravure \& Interview 精密工学の最前線}

スピンドルで高速に加工しなければな りません，そうしますと摩擦抵抗が大 きくなりますので, スパイラルタップ が主体になったり転造タップになる。 今後は転造タップ，いわゆる盛り上げ タップになるだろうと我々は考えてい ます，そのため，当社は転造タップに 力を入れ，加工が難しい鍛造された自 動車部品への使用を考えています

実は、ヨーロッパではすでに鋼加工 のタッピングは切削タップから転造夕 ップに変わりつつあります。これは 元々捨てているから関係ないのです.

Q といいますと.

A 日本では夕ップは再研磨して使 用するのですが，欧米では捨てている 場合が多いのですね。この再研磨とい うのが精度を出さなくてはいけないの で，高度な技術が必要になるのです が，欧米では自社の再研磨技術を信用 していないのです、】たがって、摩耗 したら捨てることになります。

転造夕ップは元々再研磨できません から捨てるしかないのですままた，切 らくずがでませんので, MQL 化など いろいろな意味で圧倒的に有利です。 ただ，問題は寿命ですね，切削タップ に比べてトルクが大きく，一般的には タップのサイズが太くなると寿命が落 ちますので，トルクをなるべく低くし て, 熱の発生を抑制するような設計が 重要と考えています。これからは, 高 速化というニーズからメネジ加工も切 削タップから転造工具へ，そしてプラ ネットカッタやスレッドミルの入る余 地も出てくるのではないでしようか.

Q 日本と欧米の文化の違いが工具 への考え方に表れているようですね. 日本には多くの切削工具や工作機械义 一カがありますが，我が国は「世界一」 の技術力を持っているとお考えですか.

A 世界一かどうかと聞かれると， そうですとお答えするのは難しいです が, 切削工具とか工作機械はトップク ラスの技術集団であることは間違いな
いと思います.日本企業が持つきめの 細かさと人のサービスを含めた技術が 世界的に支持されているのではないで しょうか. 私は“世界一”も重要ですが “日本発”も大切だと考えています。

\section{Q そういう意味では，深穴用超} 硬ドリルは日本が誇れる技術ですね.

A そうですね. 深穴加工用超硬ド リルも最近力を入れています.当社は タップでは評価が高いのですが,ドリ ルメーカとしてなかなか認知されなか っためで, 難しい加工に挑戦しようと して開発してきました.非常に奥が深 いですね.まず,形状が微妙であるとい うこと、次に，深いところから切りくず をスムーズに出さないといけないの で,溝の部分の表面処理·表面粗さが重 要になります.例えば, 径 $6 \mathrm{~mm}$ で 120 $\mathrm{mm}$ 位の穴をあけるとなると, 刃先の 形状がほんの少し狂っても折れやす い. 溝は表面処理をした後もう一回ポ ストコーティングをしています.もち ろん, 使用した後も再研磨・再コートを します.そのような切りくずの流出性 を高めたコーティングや再研磨技術を 含めて日本が発信した技術なので，今 後も育てていきたいと考えています.

Q ところで，貴社は 2006 年 7 月 にタンガロイ社と資本・業務提携を行 って，「オーエスジー/タンガロイグル ープ」を形成されました．このあたり の経緯や戦略について教えて下さい.

\section{A 一言で言えばシナジー効果です} ね. タンガロイ社はスローアウェイの チップを加工するメーカとしては，世 界の中でも技術力はトップクラスです し，それに彼らのもっている素材技 術，例えば，WC 粉末をつくったり cBN デイスクを焼く技術は当社には ありません，一方，OSG は巨大な加 工屋ですので, ハイス, 超硬素材, $\mathrm{cBN} ， \mathrm{PCD}$ などの素材を工具に加工 する固有の技術をもっています。この ように両者のもつ技術はだぶっていま せんので, 補完しあうことができるわ
けです，両社の技術を合体させれば， これまでにない製品を開発できると考 えています

この企画に沿った言い方をすれば， 「世界一の総合工具メーカになれるチ ヤンスを得た」ということでしょうか.

$\mathbf{Q}$ 最後に, 今回お伺いいたしま したデザインセンターの役割を含め, 今後の展開についてお聞かせ下さい.

A 過去 2004 年 11 月までは, 当社 では 4 つ製造工場でそれぞれタッ プ,エンドミル,ドリルあるいは転造工 具の設計・開発を行っておりましたここ れらは結構違った技術が背景になって おります。しかし, 将来, 当社が自動車 部品の精密切削工具の事業規模を拡大 しょうとした場合, 個々の工具ではな く,例えばクランクジャトなどの部 品にとって最適な加工方法を提案でき ることが重要だと思うのです、そのた めに, これら工具一体の開発・一体の設 計をしょうということで1筒所に集約 したのがこのデザインセンターで, 2004 年 12 月に発足しました。

今後は, 現在 3 箇所にある試験設備 を統合して基礎試験・実証試験を行う GTC(Global Technology Center), 次に, 試作品をつくる I-ROOM へと展開し ていきます.これらの組織からなる事 業所を OSG アカデミーと名付け, “今 後は研究開発からすべてここで行う” という思いが集約されているのです.

この企画は世界一ということですが， 今後はタップやエンドミルという工具 の単位だけで世界一の技術力をうたう 時代はもう終わりつつあるのではない でしょうか.例えば一つの金型をいろん な種類の工具やカッタパスを組み合わ せて総合的にサービスしていこうとい う意識をもっているのは日本のメーカ だけと思いますし，それだからこそ世界 に一定の影響力をもってリードしてい けるのではないかと思っています.

Q 大変良いお話を聞かせていた だきました．お忙しい中，長時間にわ たりありがとうございました. 